\title{
Hepatic and skeletal muscle glycogen content in rats treated with metformin and submitted to acute exercise by swimming
}

http://dx.doi.org/10.11606/1807-5509201700020355

\author{
Vitor Alexandre PEZOLATO* \\ Marcos Almeida MARQUES* \\ Fabio Marcos ABREU* \\ Nataly Mendes SILVA** \\ Ronaldo Júlio BAGANHA* \\ Rodrigo DIAS* \\ Carlos Alberto da SILVA*
}

"Faculdade de

Ciências da Saúde,

Universidade

Metodista de

Piracicaba, Piracicaba,

SP, Brasil.

"Faculdade de

Ciências da

Saúde, Faculdade

A n h a n g e r a,

Piracicaba, São Paulo,

Brasil.

\begin{abstract}
The aim of this study was to evaluate the behavior of glycogen reserves over an acute exercise condition (50 minutes of swimming at low intesity), after treatment with metformin in rats. Forty Wistar rats (180200g) adults were divided into four groups (treated or not for a fortnight) and represented as follows: Control; Acute exercise by swimming (perform a session of swimming, $50 \mathrm{~min}$ on light intensity); Treated with metformin (received the drug metformin at a dose $1.4 \mathrm{mg} / \mathrm{ml}$ during the experimental period; Treated with metformin and exercised by swimming (received the drug metformin at a dose $1.4 \mathrm{mg} / \mathrm{ml}$ and held a swimming, 50 min on light intensity). The acute exercise decreased the glycogen reserves, while animals treated with metformin showed an increase in their muscle and liver glycogen reserves $(p>0,05)$. Additionally, the drug showed no increase glucose and corticosterone concentration compared to the control and treated with metformin groups $(p>0,05)$. Treatment with metformin improved energy conditions and lowers the stress response, suggesting that an important pharmacological tool for the potentiation of performance.
\end{abstract}

KEYWORDS: Glycogen; Performance; Biguanide; Rats.

\section{Introduction}

Recent studies have demonstrated the multifactorial action of the biguanide metformin, while pharmacological agent widely used in glycemic control in patients with diabetes mellitus ${ }^{1-2}$. Within the broad spectrum of action of the substance, deserves spotlight the reduction in the production/ release of liver reserves of glucose (gluconeogenesis, glycogenolysis), increased insulin sensitivity in (especially in muscles) peripheral tissues, increased peripheral glucose utilization (by capture glucose and insulin-stimulated glycogen synthesis) and increase the population of insulin receptors (reducing hyperinsulinemia) without weight gain ${ }^{3-4}$.

Metformin formula was first published by UnGAR et $a .^{5}$ and used primarily by MAHLER et al. ${ }^{6}$ in patients with type 2 diabetes mellitus, being introduced for use in insulin resistant states, even before the development of hyperglycemia ${ }^{7}$. According to Diabetes Prevention Program Research Group $^{8}$, its effects include anti-hyperglycemic action without risk of severe hypoglycemia and a reversal of the insulin resistance process.

Metformin activates AMP-activated protein kinase (AMPK) that promotes glucose utilization", an increase in AMPK activity is associated with increased translocation of glucose transporter (GLUT)-4 to the plasma membrane, increase in hexokinase activity and glycogen content in cells muscle, in addition, there is increased oxidation of fatty acids ${ }^{10}$.

Inside the metabolic profile of skeletal muscle, it is known that preferentially uses glucose as energy substrate, which is captured in basal conditions by the carrier glucose GLUT-1 whose action is not 
dependent on insulin or the GLUT- 4 that can be translocated from cytosolic reservoirs for membrane through the action of insulin or by the increase in contractile activity ${ }^{11}$. After uptake, glucose can be oxidized or reserved in the form of glycogen, while important determinant of the efficiency of reservoir contractile process, reaching minimum values when the muscle goes into fatigue ${ }^{11}$.

The antihyperglycaemic activity of metformin is related mainly to the suppression of gluconeogenesis, block in glycogenolysis, reduction of intestinal glucose absorption, increased kinase activity of the insulin receptor, stimulation of post-insulin receptor pathways, increased translocation of GLUT-4, glucose uptake consequent elevation of the enzyme glycogen synthase activity leading to induction of the formation of large reserves of glycogen ${ }^{12-13}$. Emerging hypothesis to evaluate whether the drug promotes increased metabolic resistance against physical exercises.

\section{Methods}

\section{Sample}

It was used forty Wistar rats (Rathus novergicus var, albinus, Rodentia, Mamalia) at 3 months of age, weighing 180-200 grams, from the Vivarium of the Methodist University of Piracicaba - UNIMEP and kept in the vivarium of the Faculty of Health Sciences (FACIS-UNIMEP) under ambient temperature of $23^{\circ} \mathrm{C} \pm 2^{\circ} \mathrm{C}$, submitted to light/dark cycle of $12 \mathrm{~h}$ light, water and food ad libitum.

The study lasted 15 days, the mice were randomly divided into four experimental groups (ten animals per group): 1) Control (C); 2) Stressed by swimming (E); 3) Treated with Metformin (M); 4) Treated with Metformin and stressed by swimming (ME). All procedures used in this study were in accordance with the principles of handling and care of laboratory animals recommended by COBEA (Brazilian College of Animal Experimentation) and approved by the Ethics Committee on Animal Use of UNIMEP protocol number 09/2013.

\section{Metformin treatment}

The experimental groups treated with metformin received the substance by the orogastric via at the concentration of $1.4 \mathrm{mg} / \mathrm{ml}$ during 15 days. This
When considering the metabolic changes provided by the use of metformin, which promotes a rise in the glycogen content, the hypothesis arises that the previous use of metformin, at doses like those commonly prescribed for diabetics, may provide adjustments in energy metabolism that may be important in the practice of physical exercise. Thus the aim of this study was to evaluate, in rats eutrophics and previously treated with metformin, the behavior of glycogen reserves over a acute exercise during 50 minutes of swimming in low intensity. We emphasize that, in spite of that medication be prescribed for diabetics, recently, eutrophic individuals who begin to perform physical activity have indiscriminately used it. These individuals use the drug as a result of metabolic modulations associated with improved physical performance. So opens notorious perspective to research this use.

concentration was chosen following proposal that showed no toxicity at this concentration ${ }^{14}$. Furthermore, considering that the animal body weight changed by 180-200 grams, the correction of that delineated dosage for a $70 \mathrm{~kg}$ man would denote range of 490-544 mg, like the also delineated for insulin resistant individuals.

\section{Stress induced condition}

After fifteen days of metformin treatment in ME group and without metformin treatment in the E group, the animals underwent a single session acute exercise by swimming for 50 minutes in low intensity, performed in a tank containing water at $30 \pm 2^{\circ} \mathrm{C}^{15-16}$. The training sessions were drawn without the use of additives, which corresponds to an intensity below the anaerobic threshold, or to a predominantly aerobic stress, according to prior publication ${ }^{17}$. Such volume and the intensity chosen are justified by the fact that the same are applicable to individuals, apparently healthy and beginners in the physical exercise.

\section{Biochemical reviews}

The animals were anesthetized with sodium pentobarbital $(40 \mathrm{mg} / \mathrm{Kg}$, ip) immediately after the 
exercise and the blood was collected by renal artery, this blood was centrifuged and the plasma was separated for evaluation of plasma glucose concentration by an enzymatic kit Labortest, corticosterone was performed by immunoassay kit from Assay Designs ${ }^{\odot}$ (Ann Arbor, MI, USA). The following samples of liver, soleus and gastrocnemius white portion were carefully isolated and removed for determination of glycogen content by the phenol sulfuric acid $\operatorname{method}^{18}$.

\section{Histological analysis}

For histological analysis of the liver, its ventral segment was fixed and then processed from which various cross-sections of non-serial $5 \mu \mathrm{m}$ thick,

\section{Results}

Were observed that glycogen stores of soleus muscle were depleted by $60 \%$ due to the stress-inducing condition (E). On the other hand, in the group treated with metformin $(\mathrm{M})$ the glycogen content presented was $19 \%$ higher compared to the control $(\mathrm{C})$. In the group treated with metformin and subjected to acute exercise (ME) was observed that the glycogen content was $89 \%$ higher when compared to untreated and exercised group (E) (FIGURE 1).

Moreover, it is noted that behavior of muscle glycogen reserves of gastrocnemius white portion, on different experimental conditions, was 69\% lower because of acute exercise (E). In turn, it is noteworthy that there was an increase of $21 \%$ on glycogen reserves in the group treated with metformin (M). In assessing, the group treated with metformin and subjected to acute exercise (ME) it was found that glycogen reserves showed up 150\% larger compared to untreated and exercised group (E) (FIGURE 1).

After that, the hepatic glycogen content was evaluated, and found that the acute exercise decreases the reserves in $84 \%$ (E) if compared to the control group (C). In the group treated with metformin $(\mathrm{M})$ the hepatic glycogen reserves was increased in $57 \%$, on the other hand, in the metformin group subjected to acute exercise (ME) the reserves were 368\% higher when compared to untreated and exercised group (E). In this condition, the values were $26 \%$ lower in ME which were stained using hematoxylin-eosin (HE) were obtained.

\section{Statistical analysis}

The collected data were tabulated and analyzed using the statistical software "GraphPad Prism 6". Statistical analysis was performed by applying the Shapiro-Wilk test to verify the normality of the data.

Thus, for comparisons between groups, the statistical test for analysis of variance (one-way ANOVA) followed by Tukey-Kramer multiple comparisons for parametric data. In all cases we adopted a value of $p<0.05$ for statistical significance.

compared to the content observed in the control group (C) (FIGURE 1).

In assessing of blood glucose was found that acute exercise (E) promoted an increase of $99.4 \%$ compared to the control group (C). In the group treated with metformin $(\mathrm{M})$, the values showed no significant difference if compared to the control group (C). Already the treated and exercised group (ME) showed 38\% lower blood glucose if compared to untreated and exercised group (E) (FIGURE 1).

Within the endocrine profile, plasma corticosterone was evaluated and observed that treatment with metformin did not change the plasma concentration. On the other hand, the acute exercise group showed (E) a significant increase of $185 \%$ in the plasma concentration if compared to control group $(\mathrm{C})$, something observed in the treated and exercised group (ME), but ME had lower concentrations of corticosteroids if compared to untreated and exercised group (E) (FIGURE 1).

The histological analysis of hepatic glycogen content can show the glycogen granules, which are more abundant on the hepatocytes in treated group $(\mathrm{M})$ and treated/exercised group (ME). In the liver of exercised animals (E), there was depletion of granules mainly in the periportal region. The same did not occur with the same intensity in the treated and exercised group (ME), indicating lower reserve mobilization in the presence of biguanide (FIGURE 2). 
The results are expressed as the mean \pm SD, $\mathrm{n}=10, \mathrm{C}=$ Control, $M=$ Treated with Metformin, $E=$ Exercised by swimming, ME = Treated with Metformin and exercised by swimming. ${ }^{*} p<0,05$ comparing with group C; $\# p<0,05$ compared with group $\mathrm{M} ; . \psi \mathrm{p}$ $<0,05$ compared with group E. $227 \times 293 \mathrm{~mm}$ (300 300 DPI)
Glycogen in Soleus Muscle

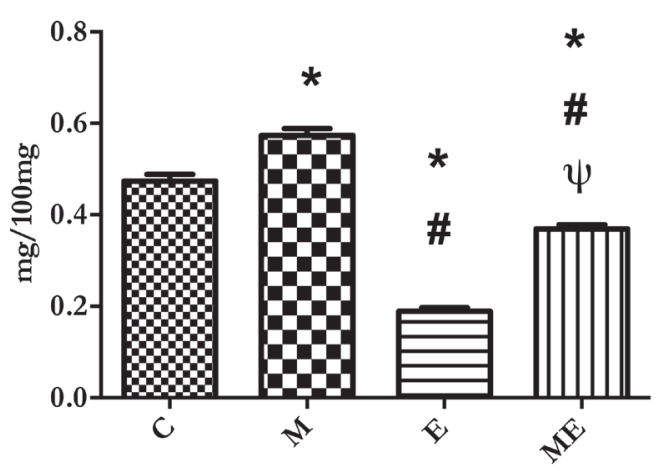

Hepatic Glycogen

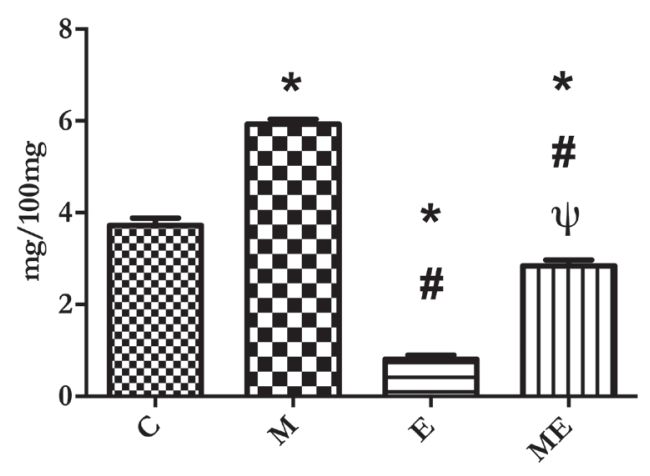

Glycogen in Gastrocnemius Muscle

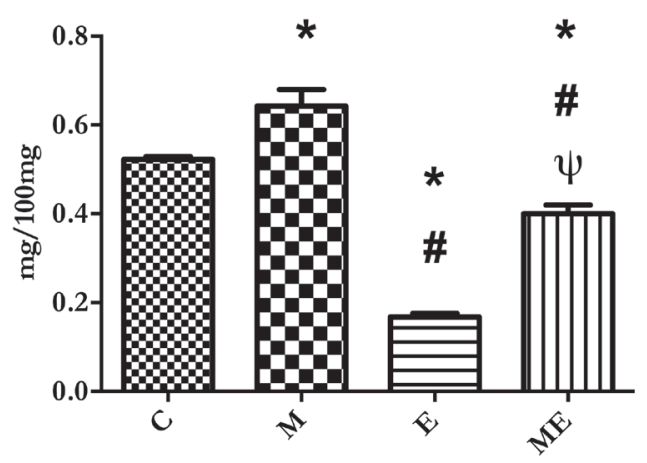

Glucose Concentration

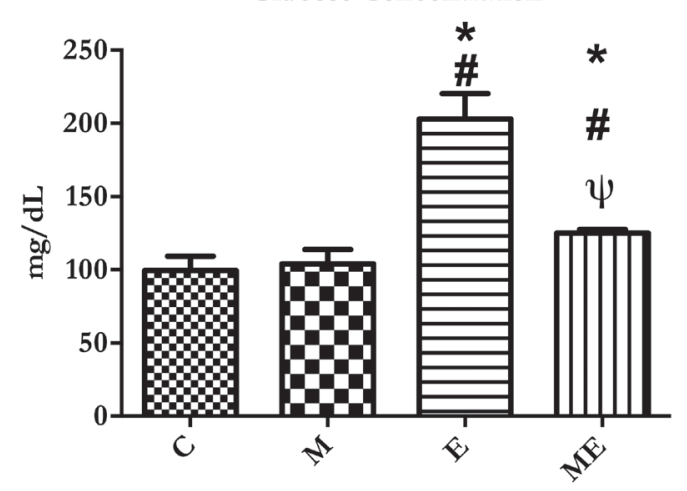

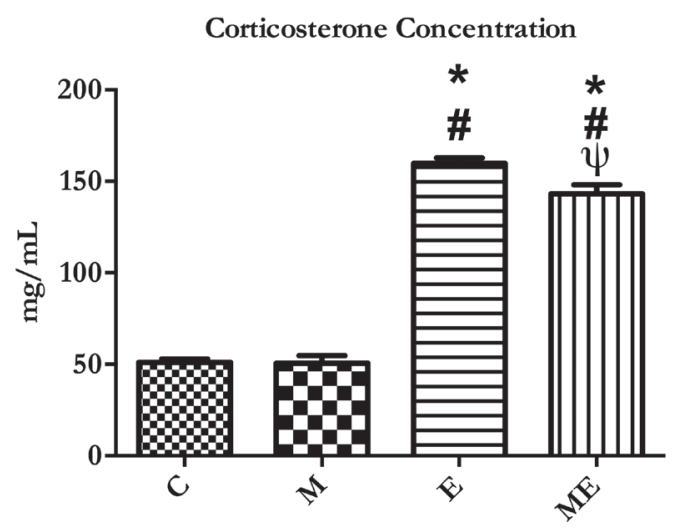

FIGURE 1 - Content of muscle glycogen, hepatic glycogen, plasma glucose and corticosterone concentration of experimental groups.

\section{Discussion}

The interrelationships between carbohydrate metabolism in the liver and muscles are studied by different scientists, since the energy reserves are determinants of resistance at physical exercise ${ }^{19}$. However, it has been noted modifications at the mobilization of these reserves concomitant to elevation at physical activity, stress or in the presence of some drugs that modify metabolic homeostasis of the organism ${ }^{20}$.

Initially we studied the effects of acute exercise induced by inescapable forced swim for 50 minutes in low 


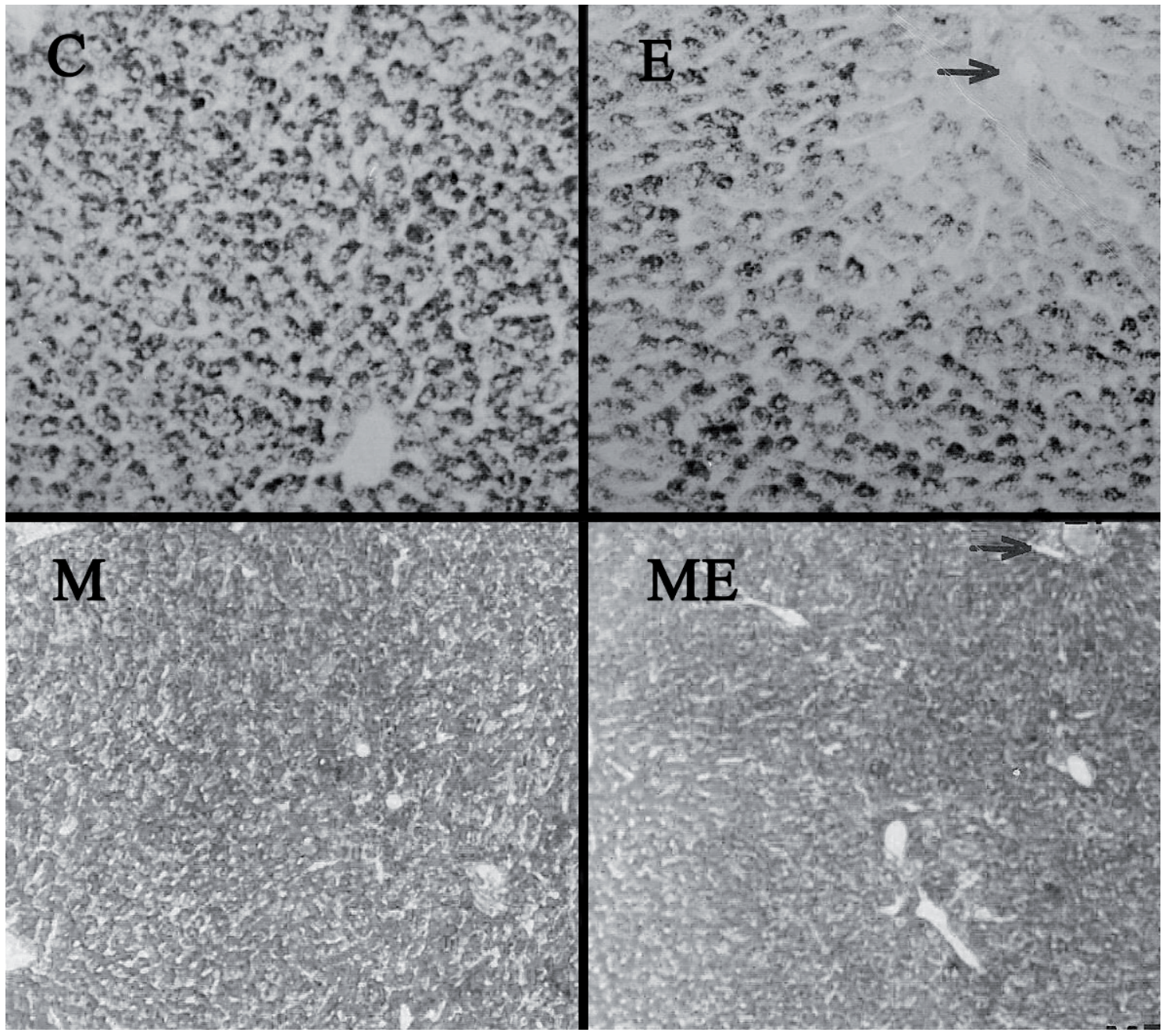

FIGURE 2 - Histology of the liver of experimental groups. Glycogen is evidenced by beads and are most abundant in hepatocytes of the treated groups ( $\mathrm{M}$ and $\mathrm{ME}$ ).
In the liver of the animals in group $\mathrm{E}$, there was depletion of glycogen granules, mainly in the periportal region (arrow). This did not occur in the group ME (arrow) (100x, PAS) $\mathrm{C}=$ Control, $\mathrm{M}=$ Treated with Metformin, $\mathrm{E}=$ Exercised by swimming, ME = Treated with Metformin and exercised by swimming. 150x133mm $(200 \times 200$ DPI $)$ intensity, proposed by SAMPAIO-BARROs et al. ${ }^{15}$, which corresponds to an intensity below the anaerobic threshold, or to a predominantly aerobic stress, according to prior publication ${ }^{17}$, on liver and muscle glycogen reserves. The data show that acute exercise condition can cause an intense depletion of hepatic glycogen stores (FIGURE 1), and can be explained by the increase in the neuroendocrine axis activity, represented by the increase in the secretion of epinephrine and norepinephrine, which activate adrenoceptor determining glycogenolysis in hepatocytes ${ }^{21}$. Occurs sequentially increase in the secretion of growth hormone, glucagon, adrenocorticotropic hormone, prolactin and opioid peptides, which also manifest glycogenolytic action, characterizing a synergistic effect ${ }^{22}$.

In order to avoid doubts and characterize the acute exercise, plasma corticosterone was evaluated and showed an increase in its concentration after physical training session (FIGURE 1), reflecting the activation of the neuroendocrine axis ${ }^{23}$.

With respect to muscle glycogen reserves, it was observed that due to the increase in energy requirements generated by the inducing acute exercise condition the reserves were depleted (FIGURE 1). These results corroborate with recent studies, which suggest that the intensity and duration of the stressor may modulate the utilization of energy substrates, with a special energy source, the degradation of muscle glycogen ${ }^{15,24-25}$.

Thus, metformin was used in this study to verify its efficiency in conditions of acute exercises, based on published reports that indicate that the biguanide promotes a significant improvement in muscle glucose metabolism ${ }^{26-28}$. 
It has been suggested that metformin does not alter the phosphorylation of the insulin receptor, and its centralized action in the post-receptor phenomena, where the biguanide promotes a rise in glucose uptake level, preserves the sensitivity of hepatocytes to insulin to regulate the activity of tyrosine kinase bound to the receptor, it enhances the dynamics of glucose uptake favoring the formation of glycogen reserves ${ }^{29}$.

In muscle, AMPK activation by metformin promotes the use of glucose, this increases the enzyme activity, causing the GLUT-4 translocation to the plasma membrane, promoting an increase in the activity of hexokinase and glycogen content in muscle cells. In addition, fatty acids undergo oxidation and reduction of the synthesis ${ }^{30}$.

In the liver, AMPK activation inhibits transcription of enzymes phosphoenolpyruvate car-boxiquinase (PEPCK) and glucose-6-phosphatase (G6Pase), generating a reduction in gluconeogenesis ${ }^{27}$. In vitro and in vivo studies demonstrated that phosphorylation of AMPK, caused by metformin, are modulated by the OCT1 activity, suggesting that this transporter has a key role in the cascade of events that result in decreased hepatic gluconeogenesis ${ }^{28}$. In addition, AMPK also promotes improvement in lipid metabolism during treatment with metformin, so that activation of this enzyme inhibit acetyl-CoA carboxylase (ACC) and 3-hydroxy-3-methylglutaryl-coenzyme and reductase (HMG-CoA reductase), key enzymes in the synthesis of triglycerides and cholesterol, respectively ${ }^{22,29,31}$. In addition, AMPK activation in the liver also suppresses the expression of SREBP-1 and SREBP-1c genes, which are involved in the pathogenesis of insulin resistance, dyslipidemia and diabetes mellitus $2^{31}$.

It's permissive to suggest that considering such molecular mechanisms associated with capitation of glucose by peripheral tissues resulting from metformin, this one has the potential to improve performance in physical exercise in predominantly aerobic conditions, due to increased energy substrate availability to meet demand from the effort. This increased availability of glucose to satisfy the demand of the aerobic effort, is crucial, since for metabolizing fats, requiring the continuous creation of oxaloacetate, recognized this metabolite is synthesized from own glucose $^{32}$. In his line of thought, studies with animal models has shown that skeletal muscle and liver glycogen reserves are related to higher physical performance, resulting in the increase in the threshold exhaustion, specifically against the effort in aerobic condition ${ }^{33-34}$.

The assessment of hepatic glycogen content of rats treated with metformin (M) showed that stocks were high (FIGURE 1), the histological analysis showed it too (FIGURE 2), and is due to metformin suppress hepatic gluconeogenesis and activate the mechanisms of glycogen synthesis by activating enzymes flag system at the level of insulin post-receptor, especially the enzyme via phosphatidyl-inositol 3 kinase $(\mathrm{Pi}-3 \mathrm{~K})$ and glycogen synthase ${ }^{31}$. Similar finding was observed in muscles treated with the biguanide, which also showed an increase in the concentration of glycogen synthesis whose actions should be elevated post-insulin receptor, similar to that described in hepatocytes ${ }^{35-37}$. It is worth mentioning that mice treated with metformin (M) showed no change in the secretion of corticosterone (FIGURE 1), showing specificity in the action of the biguanide metabolic adjustment.

In the experimental result we started to evaluate the hepatic and muscle glycogen reserves of rats treated with metformin undergoing inducing acute exercise condition (ME) being observed that the reserves were significantly higher than those observed in the untreated and exercised group (E) (FIGURE 1). This result shows that the glycogenic activity of metformin gave better energy conditions both in liver as skeletal muscle, leading to a different reaction when animals to stressful conditions and yet, the plasma concentration of glucose and corticosterona were lower compared to untreated and exercised group (E) (FIGURE 1), culminating in increased fatigue threshold and, consequently, increasing the time to exhaustion, due to the delay in decrease of muscle and liver glycogen. This suggests that the treatment led to an increased resistance against acute exercises indicating that there may be a correlation between the energy status and response to physiological stress in the conditions of this study, with a session of swimming for 50 minutes in low intensity.

A limitation of the present study was the fact that the analysis of the evaluated parameters occurred under acute exercise by swimming condition. Thus, if the evaluations of these parameters had occurred under a chronic training condition, would surely bring greater subsidies for understanding the use of metformin.

Concluding, metformin treatment modified the metabolic responses classically observed against acute exercises conditions providing greater resistance exercise confirming the study hypothesis 
initially proposed. It is noteworthy that the limiting factor of this study is the fact that the effects of the supplementation were evaluated solely on condition of acute stress. In this sense, future studies are which would be required, focusing on analysis of the chronic effects of such supplementation and during subsequent training sessions. Once the biguanide is not metabolized and is excreted in pharmacological form, this component still induces an increase of muscle and liver glycogen, enabling greater endurance. Furthermore, whereas a period of 15 days of supplementation with metformin, in eutrophic animals, has the potential to maximize the metabolic responses to acute stress by maintaining liver and musculoskeletal glycogen stores. Thus, it is necessary that the readily Word Anti-Doping Agency develop a technique for the diagnosis of use of metformin in order to identify a possible frame of doping. Further studies are required, and the physical therapists and fitness trainers shall see that the substance should not be used as an ergogenic agent.

\section{Resumo}

Reservas hepáticas e musculares de glicogênio de ratos tratados com metformina e submetidos ao exercício agudo por natação

0 objetivo deste estudo foi avaliar o comportamento das reservas glicogênicas de ratos, submetidos a uma condição de exercício agudo (50 minutos de natação na intensidade leve), após o tratamento com metformina. Quarenta ratos Wistar (180-200g) adultos foram divididos em quatro grupos (tratados ou não por quinze dias) e assim representados: Controle; Exercício agudo por natação (realizaram uma sessão de natação, sendo 50 minutos na intensidade leve); Tratado com metformina (receberam o fármaco metformina na dosagem de $1,4 \mathrm{mg} / \mathrm{ml}$, durante o período experimental; Tratados com metformina e submetidos a condição exercício agudo por natação (receberam o fármaco metformina na dosagem de 1,4 mg/ml e realizaram uma sessão de natação, sendo 50 minutos na intensidade leve). 0 exercício agudo diminuiu as reservas glicogênicas, já os animais tratados com metformina, apresentaram um aumento em suas reservas glicogênicas musculares e hepáticas em relação ao grupo que realizou o exercício sem suplementação $(p<0,05)$. Adicionalmente, o fármaco demonstrou não aumentar a glicemia e a concentração de corticosterona em relação ao grupo controle e suplementado com metformina $(p>0,05)$. 0 tratamento com metformina promoveu melhora nas condições energéticas e menor resposta ao estresse, sugerindo ser uma importante ferramenta farmacológica para a potencialização da performance.

Palavras-Chave: Glicogênio; Desempenho; Biguanida; Ratos.

\section{References}

1. Bailey CJ. Overview of new and developing pharmacological treatments. Eur Heart J Suppl 2005;7:D23-D26. Doi: 10.1093/eurheartj/sui026.

2. Eurich DT, McAlister FA. Wrongfully accused: metformin use in heart failure. Expert Rev Cardiovasc Ther 2011;9(2):147150. Doi: $10.1586 /$ erc.10.186.

3. Witters LA. The blooming of the French lilac. J Clin Invest 2001;108:1105-1107. Doi: 10.1172/JCI14178.

4. Bhathena RK. Insulin resistance and the long-term consequences of polycystic ovary syndrome. J Obstet Gynaecol 2011;31(2):105-110. Doi: 10.3109/01443615.2010.539722.

5. Ungar G, Freedman L, Shapiro S. Pharmacological studies of a new oral hypoclycemic drug. Exp Biol Med (Maywood) 1957;95(1):190-2. Doi: 10.3181/00379727-95-23163.

6. Mahler RJ. Hyperinsulinemia and non-insulin dependent diabetes mellitus. N Engl J Med 1987;316:110-112. Doi: 10.1056/NEJM198701083160214. 
7. Sigal RJ, Kenny GP, Wasserman DH, Castaneda-Sceppa C. Physical activity/exercise and type 2 diabetes. Diabetes Care 2004;27:2518-2539. Doi: 10.2337/dc06-9910.

8. Diabetes Prevention Program Research Group. Reduction in the incidence of type 2 diabetes with lifestyle intervention or metformin. N Engl J Med 2002;346:393-403. Doi: 10.1056/NEJMoa012512.

9. Zhou G, Myers R, Li Y, Chen Y, Shen X, Fenyk-Melody J, et al. Role of AMP-activated protein kinase in mechanism of metformin action. J Clin Invest 2001;108: 1167-1174. Doi: 10.1172/JCI13505.

10. Dzamko NL, Steinberg GR. AMPK-dependent hormonal regulation of whole-body energy metabolism. Acta Physiol (Oxf) 2009;196:115-27. Doi:10.1111/j.1748-1716.2009.01969.x.

11. Fryer LG, Foufelle F, Barnes K, Baldwin SA, Woods A, Carling D. Characterization of the role of the amp-activated protein kinase in the stimulation of glucose transport in skeletal muscle cells. Bioch J 2002;363:167-174.

12. Coyle EF. Carboidratos e desempenho atlético. Gatorate Spor Sci Ins 1997;9:1-5.

13. Bianchi C, Penno G, Romero F, Del Prato S, Miccoli R. Treating the metabolic syndrome. Expert Rev Cardiovasc Ther 2007;5(3):491-506. Doi: 10.1586/14779072.5.3.491.

14. Smith DL, Elam CF, Mattison JA, Lane MA, Roth GS, Ingram DK, et al. Metformin supplementation and life span in Fischer-344 rats. J Gerontol A Biol Sci Med Sci 2010;65(5):468-474. Doi: 10.1093/gerona/glq033.

15. Sampaio-Barros MM, Farias-Silva E, Grassi-Kassisse DM, Spadari-Bratfisch RC. Effect of swimming session duration and repetition on metabolic markers in rats. Stress 2003;6(2):127-132. Doi: 10.1080/1025389031000110169.

16. Jonathan ML, Ingrid HKF, Normam RJ. Metformin in polycystic ovary syndrome: systematic review and meta-analysis. Brit Med J 2003;22:1-6. Doi: 10.1136/bmj.327.7421.951.

17. Voltarelli FA, Gobatto CA, Mello MAR. Determination of anaerobic threshold in rats using the lactate minimum test. Braz J Med Biol Res 2002;35(11):1389-94.

18. Lo S, Russell JC, Taylor AW. Determination of glycogen in small tissue samples. J Apl Physiol 1970;28(2):234-6.

19. Karlsson J, Saltin B. Diet, muscle glycogen and endurance performance. J Appl Physiol 1971;31(1):203-206.

20. Eichelmann CG. Cellular response to stress. Rev Latinoam Microbiol 2006;48(2):162-172.

21. Chrousos GP. The role of stress and the hypothalamic-pituitary-adrenal axis in the pathogenesis of the metabolic syndrome: neuro-endocrine and target tissue-related causes. Int J Obes Relat Metab Disord 2000;24(2):S50-S55.

22. Tsigos C, Chrousos GP. Hypothalamic-pituitary-adrenal axis, neuroendocrine factors and stress. J Psychosom Res 2002:53(4):865-71. Doi: 10.1016/S0022-3999(02)00429-4.

23. Kyrou I, Tsigos C. Stress mechanisms and metabolic complications. Horm Metab Res 2007;39(6):430-438. Doi: 10.1055/s-2007-981462.

24. Calil CM, Marcondes FK. The comparison of immobility time in experimental rat swimming models. J Life Sci 2006;79(18):1712-1719. Doi: 10.1016/j.lfs.2006.06.003.

25. Schwanstecher C, Schwanstecher M. Targeting type 2 diabetes. Handb Exp Pharmacol 2011;203:1-33. Doi: 10.1007/9783-642-17214-4_1.

26. Guirro RRJ, Silva CA, Forti F. Análise do músculo esquelético desnervado tratado com metformina e/ou estimulação elétrica de baixa frequência. Braz J Phys Ther 2004;8(1):21-27.

27. Gross JL, Kramer CK, Leitão CB, Hawkins N, Viana LV, Schaan BD, et al. Diabetes and Endocrinology Meta-analysis. Effect of antihyperglycemic agents added to metformin and a sulfonylurea on glycemic control and weight gain in type 2 diabetes: a network meta-analysis. Ann Intern Med 2011;17(10):672-9. Doi: 10.7326/0003-4819-154-10-201105170-00007.

28. Viollet B, Andreelli F. AMP-activated protein kinase and metabolic control. Hand Exp Pharmacol 2001;203:303-330. Doi: 10.1161/01.RES.0000256090.42690.05.

29. Setter SM, Iltz JL, Thams J, Campbell RK. Metformin hydrochloride in the treatment of Type 2 Diabetes Mellitus: a clinical review with a focus on dual therapy. Clin Ther 2003; 25(12):2991-3026.

30. Zou MH, Kirkpatrick SS, Davis BJ, Nelson JS, Wiles WG, Schlattner U, et al. Activation of the AMP-activated protein kinase by the anti-diabetic drug metformin in vivo - role of mitochondrial reactive nitrogen species. $\mathrm{J}$ Biol Chem 2004;279:43940-43951. Doi: 10.1074/jbc.M404421200.

31. Nakamura SY, Thirone ACP, Carvalho CRO, Janeri L, Saad MJA. Effect of metformin on early steps of insulin signal transduction in liver and muscle of aging rats. Diabetes 1998;47(1):1148-1152.

32. MCardle DW, Katch IF, Katch LV. Fisiologia do exercício: energia, nutrição e desempenho humano. 6. ed. Rio de Janeiro: Guanabara Koogan; 2008.

33. Donatto FF, Prestes J, Frollini AB, Palanch AC, Verlengia R, Cavaglieri CR. Effect of oat bran on time to exhaustion, glycogen content and serum cytokine profile following exhaustive exercise. J Int Soc Sports Nutr 2010,7(32):1-7. 
34. Donatto FF, Prestes J, Ferreira CKO, Dias R, Frollini AB, Leite GS, et al. Efeitos da suplementação de fibras solúveis sobre as células do sistema imune após exercício exaustivo em ratos treinados. Rev Bras Med Esporte 2008;14(6):528-532.

35. Polacow MLO, Silva CA, Guirro RRJ, Campos MR, Borges JP. Estudo morfométrico do músculo sóleo desnervado de ratos tratados pela associação de metformina e estimulação elétrica. Braz J Phys Ther 2003;7(1):77-84.

36. Reddi AS, Jyothirmayi GN. Effect of chronic metformin treatment on hepatic and muscle glycogen metabolism in KK mice. Biochem Med Metab Biol 1992;47:24-132.

37. Ren JM, Semekovich CF, Gulve E, Gao J, Holloszy J. Exercise induces rapid increases in GLUT4 expression, glucose transport capacity, and insulin-stimulated glycogen storage in muscle. J Biol Chem 1994;269:14396-14401.

CORRESPONDING AUTHOR

Vitor Alexandre Pezolato

Faculdade de Ciências da Saúde

Universidade Metodista de Piracicaba

Rua Duque de Caxias, 47

CEP 13450-015

Santa Barbara d’Oeste - São Paulo - Brasil

E-mail: vitor.pezolato@gmail.com
Submitted: 10/14/2014

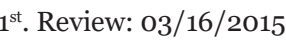

$2^{\text {nd }}$. Review: 10/28/2015

Accepted: 01/19/2016 
